\title{
PENGEMBANGAN PERANGKAT PEMBELAJARAN BERBASIS METODE PEMBIASAAN DALAM MENINGKATKAN SENSITIVITAS MORAL SISWA DI SEKOLAH DASAR
}

\author{
Sama, ${ }^{1}$, Fajar Budiyono ${ }^{2}$ \\ ${ }^{1,2}$ STKIP PGRI Sumenep \\ ${ }^{1}$ sultansamak@stkippgrisumenep.ac.id
}

\begin{abstract}
The development of learning tools based on the habituation method is one of the efforts made to familiarize students in elementary schools with activities that can increase students' moral sensitivity. The learning tools that are still used today still do not reflect how teachers accustom students to doing positive things, so that it is not optimal in improving elementary school student morale. This study aims to describe the level of effectiveness, validity, and practicality of learning tools. From the results of the development of learning tools based on the habituation method to find out the moral sensitivity of students in elementary schools before and after giving learning using the habituation method. This type of research is development research with the $4 D$ model from Thiagarajan. However, in developing learning tools using a 4-D model which is simplified into 3-D, define, design, and develop and be tested in class IV SD Taman Muda Kalianget using One Group Pretest and Posttest Design. The instruments used in this study were device validation sheets, observation sheets, and moral sensitivity assessment sheets. Data were analyzed descriptively, quantitative and qualitative. The results showed (1) the results of the learning device products developed in this study were categorized as valid. (2) The implementation of learning has been achieved through the analysis with categorized as good. (3) The results of the analysis of the moral sensitivity test show that there is an increase in the moral sensitivity of students after being given a learning process based on the habituation method based. The results of this study indicate that the learning tools based on the habituation method on the theme "Indahnya Kebersamaan" are valid, practical, and effective in increasing the moral sensitivity of elementary school students.
\end{abstract}

Keywords: habitual methods; learning tools; moral sensitivity

\begin{abstract}
Abstrak
Pengembangan perangkat pembelajaran berbasis metode pembiasaan merupakan salah satu upaya yang dilakukan untuk membiasakan siswa di Sekolah Dasar melakukan kegiatan yang yang dapat meningkatkan sensitivitas moral siswa. Perangkat pembelajaran yang masih digunakan saat ini masih belum mencerminkan bagaimana guru membiasaakn siswa untuk melakukan hal-hal yang positif, sehingga kurang maksimal dalam memperbaiki moral siswa SD. Penelitian ini bertujuan untuk mendeskripsikan tingkat kefektifan, kevalidan, dan kepraktisan perangkat pembelajaran. Dari hasil pengembangan perangkat pembelajaran dengan berbasias metode pembiasaan untuk mengetahui sensitivitas moral siswa di sekolah dasar sebelum dan sesudah pemberian pembelajaran dengan menggunakan metode pembiasaan. Jenis penelitian ini adalah penelitian pengembangan dengan model 4D dari Thiagarajan yang disederhanakan menjadi 3-D, yaitu define, design, dan develop dan diujicobakan di kelas IV SD Taman Muda Kalianget dengan menggunakan One Group Pretest and Posttest Design. Instrumen yang digunakan dalam penelitian ini adalah lembar validasi perangkat, lembar pengamatan, dan lembar penilaian sensitivitas moral. Data dianalisis secara deskriptif kuantitatif dan kualitatif. Hasil penelitian menunjukkan. (1) hasil produk perangkat pembelajaran yang dikembangkan dikategorikan valid. (2) Keterlaksanaan pembelajaran telah tercapai melalui analisis keterlaksanaan RPP dengan katagori baik. (3) Hasil analisis angket sensitivitas moral menunjukkan bahwa ada peningkatan sensitivitas moral siswa setelah diberikan proses pembelajaran dengan berbasis metode pembiasaan. Hasil penelitian ini menunjukkan bahwa perangkat pembelajaran berbasis metode pembiasaan pada tema indahnya kebersamaan valid, praktis, dan efektif dalam meningkatkan sensitivitas moral siswa Sekolah Dasar.
\end{abstract}

Kata Kunci: metode pembiasaan; perangkat pembelajaran; sensitivitas moral 


\begin{tabular}{llll}
\hline & & & \\
\hline Received & $: 2020-09-14$ & Approved & $: 2021-01-13$ \\
Reviesed & $: 2021-01-12$ & Published & $: 2021-01-31$ \\
\hline
\end{tabular}

Reviesed : 2021-01-12

Jurnal Cakrawala Pendas is licensed under a Creative Commons Attribution-

ShareAlike 4.0 International License.

\section{Pendahuluan}

Pendidikan dan masyarakat adalah dua hal yang tidak dapat di pisahkan, karena keduanya memiliki hubungan yang sangat erat. Pendidikan harus dapat membentuk karakter masyarakat bangsa Indonesia untuk menjadi bangsa yang maju, tangguh dan mencapai tujuan pendidikan nasional bangsa Indonesia. Keberhasilan pembangunan karakter bangsa ditandai dengan terwujudnya karakter bangsa yang tangguh, kompetitif, berbudi pekerti, bermoral, bertoleran, bergotong royong, patriotik, dinamis, berbudaya, dan berorientasi iptek berdasarkan pancasila dan dijiwai oleh iman dan takwa kepada Tuhan Yang Maha Esa (Kemendiknas, 2010). Dari hal itu maka pendidikan menjadi kebutuhan primer yang harus dipenuhi sepanjang hayat bagi kehidupan manusia. Pendidikan adalah bekal untuk mengejar semua yang ditargetkan oleh seseorang dalam kehidupannya. Faktanya memang tidak semua orang yang berpendidikan sukses dalam perjalanan hidupnya, akan tetapi jika dilakukan komparasi maka orang yang berpendidikan tetap jauh lebih banyak bisa meraih kesuksesan dari pada orang yang tidak pernah mengenyam pendidikan baik formal maupun non formal, namun tidak kalah penting bahwa pendidikan merupakan proses pembelajaran dalam meningkatkan moral, karakter dan tingkah laku seseorang, maka dari itu perlu pembelajaranpembelajaran dan contoh dari seorang pendidik yang dapat melatih melatih siswa dalam meningkatakn moral. Untuk mengajarkan sikap moral membutuhkan contoh dan teladan, tentang bagaimana sikap moral itu dilakukan (Gonibala et al., 2019).

Proses pendidikan di Indonesia harus mengimplementasikan sebuah pembelajaran yang mampu membangun karakter dan perbaikan dari segi afektif yang dapat memperbaiki kualitas moral siswa dan harus sesuai dengan tugas perkembangan peserta didik (Firmansyah et al., 2020). Salah satu upaya yang dilakukan pemerintah untuk mencegah terjadinya degradasi nilai-nilai etika dan moral di kalangan remaja adalah mengintegrasikan pendidikan karakter dengan mata pelajaran.

Bedasarkan hasil observasi dilapangan masih banyak pendidikan yang belum mencapai tujuan yang diharapkan, metode pembelajaran yang yang tidak sesuai dengan tugas perkembangan anak SD (Haryanti, 2017). Siswa SD memiliki karakteristik senang bermain, senang bergerak, senang berkelompok, dan senang melakukan sesuatu secara langsung. Kenyataan di lapangan proses pembelajran di sekolah dasar masing menggunakan metode yang tidak seseui dengan perkembangan dan belum mampu memberikan tauladan yang baik kepada siswa, sehingga belum mampu menyelesaikan permasalahan-permasalah moral yang sering terjadi di lapangan seperti aksi tawuran, pornografi dan pornoaksi ,merusak milik orang lain, mencuri, hilangnya sikap sopan terhadap guru, tidak menghargai teman sebayanya dan lain-lain sudah menjadi masalah sosial yang sampai saat ini masih belum di atasi secara tuntas oleh dunia pendidikan di Indonesia.Pendikan harus membentuk moral dan karkter siswa, Pembangunan kualitas pendidikan tidak dapat dilepaskan dari pembangunan karakter (Firmansyah et al., 2020).

Salah satu tujuan dari dilaksanakannya pendidikan di sekolah formal maupun non formal adalah untuk membentuk manusia yang bermoral, memiliki sikap yang terpuji, dan membentuk watak yang berbudi luhur. Oleh karena itu dibutuhkan metode pembelajaran- 
pembelajaran inovatif, metode pembelajaran yang dapat membantu siswa untuk membentuk keperibadian siswa yang bermoral berbudi pekjerti yang luhur. Dalam konteks ini metode pembelajaran pembiasaan diharapkan mampu membentuk siswa-siswa yang berakhlakul karimah, sisiwa yang bermoral, terutama pada dalam kehidupan sehari, sehingga dapat memberikan kontribusi yang nyata bagi dunia pendidikan dalam membentuk moral siswa.

Berdasarkan uraian di atas, peneliti menarik kesimpulan bahwa penelitian ini bertujuan untuk mengembangkan perangkat pembelajaran berbasis metode pembiasaan dalam meningkatkan sensitivitas moral SD ini sangat dibutuhkan. Hal ini merupakan sebagai solusi dari kemerosotan moral siswa di Indonesia secara umum dan di Kabupaten Sumenep secara khusu yang sudah mulai tampak. Out put dari penelitian ini adalah tersusunnya perangkat pembelajaran yang yang terintegrasi dengan peningkatan moral siswa, karakter dan tingkah laku yang sehingga dapat digunakan sebagai refrenbsi dan metode dalam penyelenggaraan proses pembelajaran pada jenjang SD.

Pengertian moral menurut (Hurlock, 2007) bahwa moral mengacu pada tata cara, kebiasaan dan adat peraturan perilaku yang telah menjadi kebiasaan bagi anggota suatu budaya. Sedangkan moralitas merupakan kemampuan untuk menerima dan melakukan peraturan, nilai atau perinsip moral. Syamsul (2012) mengemukakan nilai-nilai moral adalah (1) seruan untuk berbuat baik kepada orang lain, memelihara ketertiban dan keamanan, memelihara kebersihan dan memelihara hak orang lain, dan (2) larangan mencuri, berzina, membunuh, meminum-minuman keras dan berjudi. Seseorang dikatan bermoral apabila seseorang itu bertingkah laku sesuai dengan nilainilai dan moral yang di junjung tinggi di kelompok sosial (Masyarakat).

Ibrahim (2014) menyebutkan hasil survei yang dilakukan di sekolah ada dua hal pokok yang menjadi isu utama berkaitan dengan hal tersebut, yaitu hasil belajar yang meliputi sikap positif, akhlak mulia, dan budi pekerti serta keterampilan untuk hidup mandiri belum diajarkan secara "sengaja" (by design). Dalam moral diatur segala perbuatan yang dinilai baik dan perlu dilakukan, dan suatu perbuatan yang dinilai tidak baik dan perlu dihindari. Dengan demikian moral merupakan bingkai dan kendali dalam tingkah laku manusia. Moral merujuk nilai yang dianggap oleh individu dan masyarakat sebagai nilai sesuatu yang baik dan patut (Kung, 2011). Berdasarkan definisi tersebut moral adalah kebiasaan atau kemampuan sesorang untuk membedakan perbutan atau tingkah laku yang baik dan buruk. Moral yang merupakan salah satu kemampuan yang harus dikembangkan dalam potensi anak adalah ajaran baik buruknya perbuatan dan kelakuan (Ratih \& Elisabeth, 2013).

Moral merupakan kondisi mental yang membuat orang tetap berani, bersemangat, bergairah, berdisiplin dan sebainya. Moral merupakan aspek kepribadian yang diperlukan seseorang dalam kaitannya terhadap kehidupan sosial secara menyeluruh, adil, dan seimbang. Perilaku moral diperlukan demi terwujudnya kehidupan yang damai penuh keteraturan, ketertiban, dan keharmonisan dan keberanian dalam bertingkah laku di masyarakat (Asrori, 2012).

Pembiasaan adalah sebuah cara yang dapat dilakukan untuk membiasakan peserta didik berfikir, bersikap dan bertindak sesuai dengan tuntunan yang berlaku (Arief, 2012). Jika guru setiap masuk kelas mengucapkan salam, itu telah dapat diartikan sebagai usaha membiasakan. Bila murid masuk kelas tidak mengucapkan salam, maka guru mengingatkan agar ketika masuk ruangan hendaklah mengucapkan salam. Berdasarkan penelitian yang dilakukan oleh Ulya (2020) bahwa pelaksanaan metode pembiasaan di pendidikan anak usia dini Bina Generasi Tembilahan Kota dikategorikan "baik" dengan prosentase $78.57 \%$ yang berada diinterval $61 \%-80 \%$. 
Lebih lanjut Amin (2015) menyebutkan indikator pembiasaan adalah sebagai berikut: (1) Rutin, tujuannya untuk membiasakan anak melakukan sesuatu dengan baik. (2) Spontan, tujuannya untuk memberikan pendidikan secara spontan, terutama dalam membiasakan bersikap sopan santun dan terpuji. (3) Keteladanan, bertujuan untuk memberi contoh kepada anak. Metode pembiasaan sangat relevan diaplikasikan untuk anak sekolah dasar dan ada korelasi signifikan antara metode pembiasaan dalam belajar dengan disiplin anak (Ihsani et al., 2018).

Dikemukakan oleh Angdreani et al. (2020) bahwa metode pembiasaan sebagai salah satu cara yang efektif untuk menanamkan nilai-nilai keagamaan siswa karena dilatih dan dibiasakan untuk melakukannya setiap hari. Halimah \& Zulfahmi (2019) menyatakan metode pembiasaan ini sangat diutamakan dalam pengembangan akhlak atau moral keagamaan anak, karena semua yang ada di dunia ini diawali dengan membiasakan anak dengan moral yang baik sehingga keimanan dan ketaqwaan kepada Allah SWT tertanam didalam diri sejak dini. Ihsani et al. (2018) mengemukakan terdapat hubungan yang signifikan antara metode pembiasaan dengan disiplin anak usia dini. Dari berbagai definisi diatas, maka dapat disimpulkan bahwa pembiasaan merupakan hal yang selalu di lakukan berkali-kali dan berkesinambungan sesuai dengan kaidah, nilai dan norma-norma yang berlaku dalam masyarakat dan agama, sehingga bisa membuat anak didik merasa terbiasa melakukan kegiatan-kegiatan yang positif dalam hati maupun tingkah laku.

Kelebihan metode pembiasaan diantaranya: (1) Dapat menghemat tenaga dan waktu dengan baik. (2) Pembiasaan tidak hanya berkaitan dengan aspel lahiriyah, tetapi juga berhubungan dengan aspek batiniyah. (3) Pembiasaan dalam sejarah tercatat sebagai metode yang paling berhasil dalam pembentukan kepribadian peserta didik (Khorida, 2013).

Penelitian ini menggunakan metode pembiasaan dalam meningkatkan sensitivitas moral siswa di SD dimana pada penelitian ini mengambil tema indahnya kebersamaan, tema tersebut merupakan sarana pembelajran kepada siswa sekolah dasar untuk selalu terbiasa berfikir dan bertindak sesuai dengan norma, nilai yang berlaku di dalam masyarakat terutama dalam lingkukan pertemanan di sekolah, karena dalam tema ini selain di jelaskan tentang pengetahuan secara kognitif juga mengajarkan kepada siswa untuk selalu menghargai sesama, pentingnya kebersamaan dan membentuk moral yang berbudi luhur dalam kehidupan seharihari supaya anak menjadi berkarakter dan bermoral yang baik.

\section{Metode Penelitian}

Jenis penelitian ini termasuk jenis penelitian pengembangan (development research) yang di fokuskan pada perangkat pembelajaran tema indahnya kebersamaan dengan berbasis metode pembiasaan dalam meningkatkan sensitivitas moral siswa di sekolah dasar. Subyek dalam penelitian ini ialah perangkat pembelajaran berbasis pembiasaan pada tema indahnya kebersamaan. Subjek ini di gunakan untuk keperluan implementasi perangkat pembelajaran pada siswa kelas IV Sekolah Dasar Taman Muda Kecamatan Kalianegt Kabupaten Sumenep Tahun Ajaran 2019/2020.

Penelitian pengembangan atau Reseach and Development (R \& D) merupakan metode penelitian yang digunakan untuk menghasilkan produk tertentu dan menguji keefektifan produk tersebut (Sugiyono, 2012). Model ini terdiri dari 4 tahap pengembangan, yaitu: (1) Tahap Pendefinisan (Define). (2) Tahap Perancangan (Design). (3) Tahap pengembangan (Develop), dan (4) Tahap Pendesiminasian (Dissemination). Desain dalam kegiatan penelitian ini, pada saat ujicoba di kelas menggunakan model The One Group Pretest-Postest Design, karena 
hanya menggunakan satu kelompok saja tanpa adanya kelompok lain sebagai pembanding dalam one-group pretest-postest design, sebuah kelompok diukur atau diamati tidak hanya setelah perlakuan, tetapi juga sebelumnya. Sebelum perlakuan, sampel diberikan terlebih dahulu pretest (tes awal) dan di akhir pembelajaran sampel diberi postest (tes akhir).

Teknik Pengumpulan Data dalam penelitian ini peneliti menggunakan tiga teknik pengumpulan data yaitu: (1) Pengamatan (observasi). Pengamatan adalah kegiatan pemuatan perhatian terhadap sesuatu objek dengan menggunakan seluruh indra. Kegiatan observasi (observation) meliputi melakukan pengamatan, pencatatan secara sistematik kejadian-kejadian, perilaku, objek-objek yang dilihat dan hal-hal lain yang diperlukan dalam mendukung penelitian yang sedang dilakukan. Metode ini digunakan untuk pengumpulan data aktivitas siswa, keterlaksanaan RPP, dan hambatan-hambatan dalam KBM. (2) Angket (kuesioner) Pada penelitian ini, angket (kuesioner) digunakan untuk memperoleh informasi yang berkaitan dengan respon siswa terhadap penggunaan perangkat pembelajaran yang meliputi buku siswa, lembar kerja (LKS), suasana belajar, dan cara guru dalam proses pembelajaran. (3) Tes sensitivitas moral. Tes adalah suatu serentetan pernyataan atau laithan serta alat lain yang digunakan untuk mengukur keterampilan, pengetahuan intelegensi, kemampuan atau bakat yang dimiliki oleh individu atau kelompok. Metode ini digunakan untuk mengumpulkan data kemampuan siswa tentang sensitivitas moral atau afiktif.

Instrumen yang digunakan dalam penelitian ini adalah instrumen untuk mengukur validitas perangkat pembelajaran yang dikembangkan. Validitas perangkat pembelajaran diukur dengan menggunakan lembar penilaian atau lembar validasi yang sudah dinyatakan valid berdasarkan hasil penilaian ahli. Lembar validasi yang di gunakan dalam penelitian ini yaitu (1) lembar oservasi siswa, (2) lembar validasi RPP, (3) lembar validasi angket sensitivitas moral siswa

\section{Hasil dan Pembahasan}

\section{Data Hasil Pengembangan Perangkat Pembelajaran}

Perangkat pembelajaran yang dikembangkan dalam penelitian ini adalah perangkat pembelajaran yang meliputi RPP, Lembar Kerja Siswa (LKS) dan Tes Hasil Belajar (THB) untuk aspek sensitivitas moral. Metode yang digunakan dalam perangkat pembelajaran ini adalah metode pembiasaan. Kegiatan proses pembelajaran dengan menggunakan metode pembiasaan yang diterapkan dalam RPP ini secara langsung dapat melatihkan siswa dalam membiasakan tingkah laku yang positif, karena dalam proses pembelajaran dengan menggunakan metode pembiasaan siswa akan di latih untuk melakukan hal-hal yang baik dalam kehidupan sehari-hari dengan cara berulang agar siswa terbiasa dengan aktivitas itu sendiri. Kegiatan yang dilaksanakan secara terus menerus akan membuat siswa merasa terbiasa dan pada akhirnya akan membentuk sebuah karakter yang baik dalam diri siswa itu sendiri, sehingga siswa di tuntut untuk membiasakan diri dalam melakaukan hal-hal yang positif dan bemoral. Hal ini di perkuat dengan pendapat oleh (Djaali, 2013) mengungkapkan bahwa pembiasaan merupakan cara bertindak yang diperoleh melalui belajar secara berulangulang, yang pada akhirnya menjadi menetap dan bersifat otomatis. Sehingga perangkat pembelajran dengan menggunakan metode pembiasaan mampu merubah moral siswa yang sebelumnya menunjukkan hal-hal yang negatif, seperti hilangnya tatakram terhadap guru di sekolah, sering bertengkar dengan teman sebaya, tauran antar kelas bias menjadi lebih baik baik, karena dalam proses pembelajaran yang di kembangkan siswa dibiasakan untuk melakukan hal-hal yang positif, seperti mengaji sebelum pelajaran dimulai, bersalaman kepada guru sebelum masuk kelas, sudah tidak ada perkelahian di sekolah. 
Lembar Kerja Siswa yang di kembangkan dalam penelitian ini sebnyak dua buah LKS. Ujicoba yang disajikan di dalam Lembar Kerja Siswa di di cantumkan gambar-gamar yang dapat mendukung sikap kebiasaan siswa dengan kehidupan realita sehari-hari. Lembar Kerja Siswa di pakai oleh siswa sebagai pedoman dalam memperaktikkan secara konsep dan teori dalam kehidupan sehari-hari baik di sekolah maupun di luar sekolah, sehingga bisa membuat anak didik merasa terbiasa melakukan kegiatan-kegiatan yang positif dan berkarakter baik. Proses pendidikan karakter religi dengan memakai metode pembiasan telah dapat meningkatkan aktifitas siswa dalam melaksanakan ibadah serta dapat meningkatkan karakter yang baik siswa dalam kehidupan seharihari (Mutakin et al., 2014)

Tes Hasil Belajar yang dikembangkan oleh peneliti yaitu terdiri dari satu jenis, yaitu Angket sensitivitas moral, angket sensitivitas moral terdiri dari lima pertanyaan, yang di kembangkan berdasarkan indikator sensitivitas moral siswa yang sudah disusun berdasarkan tujuan pembelajaran, sehingga dapat digunakan untuk mengukur ketercapaian tujuan pembelajaran.

\section{Hasil Validasi Perangkat Pembelajaran}

Rencana Pelaksanaan Pembelajaran (RPP) sudah divalidasi oleh dua orang ahli sebelum diaplikasikan dalam proses pembelajaran yang di berikan kepada siswa. Koreksi dan validasi RPP oleh seorang ahli bertujuan untuk memperoleh hasil yang relevan dan masukan dari orang yang ahli untuk perbaikan RPP sehingga kemudian layak untuk digunakan dalam proses pembelajaran. Berdasarkan hasil validasi dari dua orang ahli untuk Rencana Pelaksanaan Pembelajaran, diperoleh jumlah atau skor rata-rata keseluruhan adalah 3,4 termasuk kategori cukup baik serta kevalidan dari perangkat tersebut menunjukkan katagori valid dengan penafsiran kevalidan sebesar 85\%. Lembar Kegiatan Siswa (LKS) untuk menopang proses pembelajaran. Lembar Kegiatan Siswa yang telah dikembangkanoleh peneliti harus divalidasi oleh ahli untuk mendapatkan masukan dan perbaikan sebelum diaplikasikan dalam proses pembelajaran. Berdasarkan validasi dari dua ahli untuk Lembar Kegiatan Siswa untuk siswa, diperoleh jumlah atau skor rata-rata adalah 3,2 termasuk kategori baik dan kevalidan dari LKS tersebut termasuk katagori valid dengan kevalidan sebesar 84\%. Tes Hasil Belajar Aspek sensitivitas Moral. Jenis soal yang dikembangkan dalam penelitian ini adalah soal uraian tentang masalah sosial dalam kehidupan sehari sebanyak lima soal yang mewakili terhadap indikator sensitivitas moral. Berdasarkan hasil validasi dari dua ahli untuk butir soal diperoleh diperoleh jumlah atau skor rata-rata keseluruhan adalah 3.7 termasuk kategori baik serta kevalidan dari soal tersebut menunjukkan katagori sangat dengan penafsiran kevalidan sebesar $92 \%$.

Perangkat pembelajaran yang dikembangkan oleh peneliti disusun berdasarkan kepada langkah-langkah metode pembiasaan yang diharapkan dapat menjadi pembelajaran yang mengintegrasikan aspek kognitif dengan sikap sosial dan spiritual dan disesuaikan dengan kebutuhan penelitian untuk melatihkan sensitivitas moral siswa. Hasil rekapitulasi validasi perangkat pembelajaran dengan model pemaknaan untuk melatihkan sensitivitas moral disajikan pada tabel berikut:

Tabel 1. Rekapitulas Hasil Validasi Perangkat Pembelajaran

\begin{tabular}{cccc}
\hline Perangkat & Skor rata-rata & Kevalidan $\%$ & Katagori \\
\hline RPP & 3,4 & $85 \%$ & Baik \\
LKS & 3,2 & $84 \%$ & Baik \\
THB & 3,7 & $92 \%$ & Baik \\
\hline
\end{tabular}


Implementasi Perangkat Pembelajaran pada Uji Coba 1 dan 2

Penelitian dilaksanakan sebanyak 2 kali pertemuan. Pertemuan pertama dilaksanakan untuk memberikan pretest kepada siswa sebanyak 13 orang dan pertemuan ke dua di laksanakan untuk memberikan post-tes kepada kelas dan siswa yang sama guna mendapatkan deskripsi mengenai sensitivitas moral siswa, dan pada saat penelitian uji coba 1 dan ujicoba 2 peneliti bertindak sebagai pengajar, dan dibantu oleh observer.

\section{Hasil Analisis Keterlaksanaan Pembelajaran}

Hasil analisis keterlaksanaan RPP dimaksudkan untuk mendeskripsikan proses kegiatan pembelajaranr. Untuk mengetahui keberhasilan implementasi perangkat pembelajaran, proses kegiatan pembelajaran diamati oleh dua observer dengan menggunakan lembar pengamatan keterlaksanaan RPP. Aspek yang diamati dalam analisis keterlaksanaan RPP yaitu meliputi kegiatan pendahuluan, kegiatan inti, kegiatan penutup dan pengolahan waktu dan suasan kelas. berdasarkan hasil pengamatan yang dilakukan oleh dua observet terhadap keterlaksanaan RPP dari proses pembelajaran dengan berbasis metode pembiasaan diperoleh jumlah disajikan pada tabel berikut:

Tabel 2. Rekapitulas Hasil Keterlaksanaan RPP

\begin{tabular}{cccc}
\hline Aspek & Skor Rata-rata & Ketercapaian \% & Katagori \\
\hline Pendahuluan & 3,6 & $87 \%$ & Baik \\
Kegiatan inti & 3,7 & $89 \%$ & Baik \\
Kegiatan penutup & 3,6 & $87 \%$ & Baik \\
Pengelolaan waktu & 3,8 & $90 \%$ & Baik \\
Suasana kelas & 3,9 & $95 \%$ & Sangat baik \\
\hline
\end{tabular}

\section{Hasil Analisi Angket Sensitivitas moral}

Hasil Angket Sensitivitas moral siswa ada tema indahnya kebersamaan dengan berbasis metode pembiasaan diketahui dari nilai siswa yang diperoleh dari menjawab angket sensitivitas moral. Skor sensitivitas moral yaitu 1 sampai 4 dalam setiap pertanyaan persentase tingkatan sensitivitas moral siswa pada saat pretest dan posttest . skor rata-rata pretest hasil angket sensitivitas moral adalah 3,0 dan setelah proses pembelajaran menggunakan metode pembiasaan skor rata-rata 3,9.seperti ditunjukkan tabel berikut :

Tabel 3. Angket Aspek Sensitivitas Moral Siswa

\begin{tabular}{ccc}
\hline Sensitivitas moral & Skor rata-rata & Sensitif \\
\hline Pre-tes & 3,0 & 50,6 \\
Post-tes & 3,9 & 89,3 \\
\hline
\end{tabular}

Hasil analisis angket sensitivitas moral menunjukkan bahwa ada peningkatan sensitivitas moral siswa setelah diberikan proses pembelajaran dengan berbasis metode pembiasaan. Berdasarkan tabel diatas bahwa skor rata-rata pretest hasil Angket sensitivitas moral adalah 3,0 dan setelah posttes skor rata-rata 3,9. skor tesebut menunjukkan ada peningkatan yang sangat signifikan terhadap senisitivitas moral siswa, dapat di tarik kesimpulan bahwa setalah diberikan proses pembelajran berbasis metode pembiasaan sebagian besar siswa berada pada tingkat sensitiv yang tinggi, siswa sudah terbiasa melakukan hal-hal yang positif, seperti bersalaman sebelum masuk kelas, menunduk ketika lewat di depan guru dan terbiasa membuang sampah pada tempatnya. Hal ini menunjukkan bahwa terjadi perubahan nilai moral setelah siswa di biasakan melakukan hal-hal yang positif. Sensitivitas moral juga sama seperti apsek psikologis lainnya, sensitivitas moral bisa di rubah dan di pengaruhi oleh oleh lingkungan sekitar. Sensitivitas moral dapat mangalami 
peningkatan secara alamai dan juga dengan cara dibiasakan yang dalam hal ini adalah prose pendidikan. Bagi siswa yang masih memiliki jiwa ego yang sangat tinggi, guru harus memberikan kegiatan bimbingan dan membiasakan siswa dalam memahami tingkah laku dan tatakrama yang terjadi dalam kehidupan sehari-hari baik di sekolah maupun di luar sekolah. Penilaian terhadap moral siswa bertujuan untuk mengetahui karakter, perasaan, dan tingkah laku yang di hasilkan dari perilaku pembiasaan melalui pendidikan,

Ketercapaian dari angket sensitivitas moral merupakan hasil produk dari pengembangan perangkat pembelajaran berbasis metode pembiasaan. Hasil dari validasi perangkat pembelajaran (RPP, LKS dan THB aspek angket sensitivitas moral) memiliki katagori valid sehingga layak untuk aplikasikan sebagai perangkat pembelajaran dalam meningkat sensitivitas moral siswa. Aspek sensitivitas moral meliputi tentang indikatorindikator sensitivitas moral yang terdapat dalam RPP dengan menggunakan metode pembiasaan dan di sajikan dalam bentuk gambar di dalam LKS berdasarkan tema indahnya kebersamaan untuk kemudian dijadikan latihan siswa dalam memahami konsep dan teori terkait dengan pembiasaan. Komponen moral dalam LKS merupakan komponen yang berbeda dengan LKS yang ada secara umum. Pengembangan sensitivitas moral dari konsep tema indahnya kebersamaan tanpa mengurangi ciri khas sebagai LKS yang ada. Siswa diajak untuk berpikir sesuai dengan indikator sensitivitas moral yang ingin dikembangkan oleh peneliti.indikator nilai yang ingin dimunculkan dari sensitivitas moral dibuat mudah digunakan dan sederhana.

Metode pembiasaan melatih siswa terbiasa melakukan sesuatu dalam kehidupan sehari-hari untuk menagkapkan pesan moral yang terdapat pada tema indahnya kebersamaan. Dalam proses pembelajaran di sajikan cerita tentang kehidupan yang meninspirasi dan vediovedio yang berkatan dengan moral untuk melatih siswa dalam meningkatkan sensitivitas moral yang dimilikinya.senada dengan penelitian yang (Machfiroh et al., 2019). Pembentukan karakter anak dapat dilakukan dengan menggunakan metode pembiasaan, (1) guru membiasakan anak untuk datang tepat waktu, (2) guru membiasakan anak untuk mengembalikan barang ke tempat semula, (3) guru membiasakan anak untuk membereskan mainan setelah bermain di dalam kelas, (4) guru membiasakan anak untuk bersabar dan tertib dalam menunggu giliran cuci tangan, dan (5) petugas kebersihan membiasakan anak untuk mengantri ketika ke kamar mandi. Metode pembiasaan dapat membentuk karakter disiplin, jujur, tanggungjawab, mandiri dan sopan santun. Dengan demikian sikap, tinkah laku, perasaan, dapat ditingkan dengan menggunakan metode pembiasaan.

\section{Kesimpulan}

Berdasarkan hasil penelitian dan pemahasan diatas dapat disimpulkan bahwa perangkat pembelajaran dengan berbasis metode pembiasaan pada tema indahnya kebersamaan sudah valid, efektif dan praktis sehingga sudah layak aplikasikan dalam proses kegiatan pembelajaran di Sekolah Dasar dalam meningkatkan sensitivitas moral siswa. Perangkat pembelajaran dengan berbasis metode pembiasaan pada tema indahnya kebersamaan dengan skor keterlaksanaan RPP berada pada kategori sangat baik. Hasil penilaian RPP, Lembar Kerja Siswa dan Hasil Tes Belajar (THB) aspek moral yang sudah di nilai oleh validator telah memenuhi kriteria valid dengan kualitas kevalidan baik. Berdasarkan hasil angket sensitivitas moral siswa perangkat yang di kembangkan telah menunjukkan kreteria sensitivitas yang sangat baik dalam meningkatkan moral siswa. Perangkat pembelajaran berbasis metode pembiasaan yang di gunakan dalam meningkatkan sensitivitas 
moral siswa lebih baik daripada menggunakan perangkat pembelajaran dengan menggunakan metode konvensional. Dengan demikian dapat disimpulkan bahwa perangkat pembelajaran dengan berbasis metode pembiasaan telah valid, praktis dan efektif sehingga dapat digunakan pada proses pembelajaran di SD. Penggunaan perangkat pembelajaran berbasis metode pembiasaan ini mampu meningkatkan sensitivitas moral siswa SD, akan tetapi metode pembiasaan terhadap peningkatan moral perlu diaplikasikan tidak hanya pada proses pembelajaran namun juga harus di aplikasikan di luar pembelajaran, di lingkungan sekolah dan juga di rumah, sehingga siswa mampu secara maksimal dalam memperbaiki dan meningkatkan moral sisiwa itu sendiri.

\section{Daftar Pustaka}

Amin, M. M. (2015). Pendidikan Karakter Anak Bangsa. Hak Cipta.

Angdreani, V., Warsah, I., \& Karolina, A. (2020). Implementasi Metode Pembiasaan: Upaya penanaman Nilai-Nilai Islami Siswa SDN 08 Rejang Lebong. At-Ta'lim, 19(1), 1-21.

Arief, A. (2012). Pengantar Ilmu dan Metodologi Pendidikan Islam. Ciputat Pers.

Asrori, M. A. \& M. (2012). Psikologi Remaja; Perkembangan Peserta Didik. PT Bumi Aksara.

Djaali. (2013). Psikologi Pendidikan. Bumi Aksara.

Firmansyah, F., Purwati, P., Siregar, N. N., \& Irfa, I. (2020). Integrasi Pendidikan Karakter Rasa Ingin Tahu Pada Pengembangan Bahan Ajar Matematika SD. Jurnal Cakrawala Pendas, 6(2), 143-155.

Gonibala, A., Pikoli, M., \& Kilo, A. La. (2019). Validitas Perangkat Pembelajaran Materi Ikatan Kimia berbasis Model Pembelajaran Pemaknaan untuk Melatihkan Sensitivitas Moral Siswa SMA. Jambura Journal of Educational Chemistry, 1(1), 1-6.

Halimah, R., \& Zulfahmi. (2019). Implementasi Metode Pembiasaan Dalam Pengembangan Moral Keagamaan Aud Kelompok B di RA An-Najwan Desa Kebun Balok Kabupaten Langkat. Jurnal Raudhah, 7(2), 1-19.

Haryanti, Y. D. (2017). Model Problem Based Learning Membangun Kemampuan Berpikir Kritis Siswa Sekolah Dasar. Jurnal Cakrawala Pendas, 3(2), 57-63.

Hurlock, E. (2007). Perkembangan Anak (jilid 2). Erlangga.

Ibrahim, M. (2014). Model pembelajaran inovatif melalui pemaknaan (belajar perilaku positif dari alam). Unesa University Press.

Ihsani, N., Kurniah, N., \& Suprapti, A. (2018). Hubungan Metode Pembiasaan dalam Pembelajaran dengan Disiplin Anak Usia Dini. Jurnal Ilmiah Potensia, 3(1), 50-55.

Kemendiknas. (2010). Pengembangan Pendidikan Budaya dan Karakter Bangsa. Puskur-Balitbang. Kemendiknas.

Khorida, M. F. \& L. M. (2013). Pendidikan Karakter Anak Usia Dini: Konsep \& Aplikasinya dalam Paud. Ar-Ruzz Media.

Kung, W. N. (2011). Pendidikan moral. Chengage Learning Pte Ltd.

Machfiroh, L., Desyanty, E. S., \& Rahmah, R. A. (2019). Pembentukan Karakter Disiplin Anak Usia Dini Melalui Metode Pembiasaan Di TK Aisyiyah Bustanul Athfal 33 Kota Malang. Jurnal Pendidikan Nonformal, XIV(1), 54-66.

Mutakin, T. Z., Indra, N., \& Rusmana, M. (2014). Penerapan Teori Pembiasaan dalam Pembentukan Karakter Religi Siswa di Tingkat Sekolah Dasar. Jurnal Edutech Edutech, 1(3), 1-13.

Ratih, R., \& Elisabeth, C. (2013). Penggunaan Metode Pembiasaan Dalam Meningkatkan Perilaku Moral Anak Kelompok B Di Tk Bina Anak Sholeh Tuban. Jurnal BK UNESA, $4(1), 329-337$.

Sugiyono. (2012). Metode Penelitian Kuantitatif Kualitatif dan $R \& D$. Alfabeta.

Syamsul, Y. (2012). Psikologi perkembangan anak dan remaja. PT Remaja Rosdakarya.

Ulya, K. (2020). Pelaksanaan Metode Pembiasaan Di Pendidikan Anak Usia Dini Bina Generasi Tembilahan Kota. Asatiza, 1(1), 49-60. 